Петро Гушоватий, професор кафедри методики музичного виховання $і$ диригування Дрогобищького державного педагогічного університету імені Івана Франка

\title{
ДО ІСТОРІЇ ХОРОВОГО МИСТЕЦТВА ТЕРНОПІЛЬЩИНИ: ЯРОСЛАВ СМЕРЕЧАНСЬКИЙ ХОРОВИЙ ДИРИГЕНТ, КОМПОЗИТОР, ПЕДАГОГ (до 110-ї річниці від дня народження)
}

Стаття містить матеріали про відомого на Поділлі самодіяльного композитора, хорового диригента, громадського діяча, Ярослава Васильовича Смеречанського.

Ярослав Смеречанський - диригент і організатор багатьох хорових колективів (більше 40 хорів), засновник музичної школи в містечку Заліщики на Тернопільщині, автор більще 500 композицій: для хору, оркестру, бандури. Як педагог музичної школи виховав цілу плеяду учнів, щзо стали професійними музикантами, педагогами, які працюють у відомих колективах, навчальних закладах України та за кордоном.

Ключові слова: диригент; хормейстер; хорове мистеитво; хор; самодіяльний композитор.

Jim. 4.

Petro Hushovatiy, Professor of the Methodology of Music Education and Conducting Department Drohobych Ivan Franko State Pedagogical University

\section{TO THE HISTORY OF CHORALART IN TERNOPIL REGION: YAROSLAV SMERECHANSKIY - THE CHOIR CONDUCTOR, COMPOSER, TEACHER} (to the 110th anniversary of his birthday)

The article contains the materials about the well-known amateur composer, choral conductor, public figure, Yaroslav Vasylovych Smerechanskiy, who is well-known in Podillya.

Yaroslav Smerechansky is the conductor and organizer of many choir collectives (40 choruses), the founder of the music school in the town of Zalishchiki in Ternopil region, and has authored more than 500 compositions: for choir, orchestra, bandura.

Yaroslav Smerachansky was born on April 18, 1909 in the town Kolomyia in the Stanislav region (now Ivano-Frankivsk region) in the family of railway workers.

In 1932 Y.Smerechanskiy graduated from the Lviv Conservatory (class of Prof. S.Krebs - violin). In the same year he starts to lead the choir of the Polish "Tovarystva lyudovoho" in the town of Horodenka in Stanislavskiy region. Simultaneously, he manages the city choir "Boyan" and organizes the choral groups in surrounding villages - Strelce and Yaseniv-Pyliv. And later - in Chernelytsya and Kopychyntsi.

Since the beginning of the war in 1941, the composer moves to Zalishchyky. The choir hosted here participated in the First Land Competition of the Galician Choruses dedicated to the 100th anniversary of the birth of M. Lysenko, which took place in Lviv in 1942.

Among the most extensive creative heritage of the composer, the most popular are his choral compositions "Pasla divka lebedi", "Bistra voda", Shevchenko poetry - "Zapovit" - for soloist-bass and male choir (this work was used by Lesya Tsaliy-Yakimenko in her Thesis on the topic "Zapovit” by Taras Shevchenko in music "(1964), "Husarka", "Selo". The most famous, in our opinion, is the composition of Y.Smerechanskiy on the poetry of T. Shevchenko "Teche voda v synye more".

In 1947 he organized the children's music school in Zalishchyky, which was opened in September in 1946 as a subsidiary of Chortkiv school. Thanks to the efforts of Smerechanskiy since 1947, it began to act as an independent music institution. V.Smerechskiy died in 2002 in Zalishchyky city.

Keywords: a conductor; a choirmaster; choir art; a choir; an amateur composer.

П остановка проблеми. Серед відомих діячів українського хорового мистецтва Поділля минулого XX століття значне місце посідає знаний диригентхормейстер, музикант-педагог, активний подвижник на ниві української культури, член Національної Ліги композиторів, Ярослав Васильович Смеречанський.

Народні пісні в його обробках у виконанні відомих хорових колективів та ансамблів України і нині милують слух численних шанувальників українського вокально-хорового мистецтва. Багато учнів Я. Смеречанського плідно працюють на ниві української музичної культури по всій Україні і далеко за їі межами. Разом з тим багатогранна діяльність його ще не отримала належного висвітлення у наукових дослідженнях.

Мета статті полягає в тому, щоб познайомити 


\section{ДО ІСТОРЇ ХОРОВОГО МИСТЕЦТВА ТЕРНОПІЛЫЩИНИ: ЯРОСЛАВ СМЕРЕЧАНСЬКИЙ ХОРОВИЙ ДИРИГЕНТ, КОМПОЗИТОР, ПЕДАГОГ}

(до 110-ї річниці від дня народження)

широке коло читачів, науковців, педагогівмузикантів 3 життям і діяльністю Ярослава Смеречанського.

Виклад основного матеріалу. Народився Ярослав Васильович Смеречанський 18 квітня 1909 року в містечку Коломия на Станіславівщині (тепер Івано-Франківська область) в сімї залізничника [2, 527].

3 дитинства Ярослав виявив неабиякі музичні здібності. Тому батьки послали його навчатися гри на скрипці. Та найпершими кроками у його музично-педагогічній діяльності було керівництво студентським хором Заліщицької педагогічної семінарії, де Я. Смеречанський навчався.

Слід нагадати, що директором на той час був відомий український поет, прозаїк, публіцист, критик, літературознавець, перекладач, редактор багатьох періодичних видань,педагог, громадськополітичний діяч Осип Маковей.

“Осип Маковей, - згадував згодом Я. Смеречанський, - директор учительської семінарії - мій вчитель залишив після себе у пам'яті заліщан незгладимий слід. Він був тією людиною, яка присвятила своє життя служінню народові, боротьбі за національне визволення. Для мене, для всіх учнів семінарії був учителем, добрим порадником, другом" $[4,6]$.

Саме для семінарського хору юний Ярослав написав свою першу пісню-колядку “Ой сумні поля та люди”. Напевне вона надихнула його на майбутньому життєвому виборі - професійного музиканта.

В 1932 році Я. Смеречанський закінчує Львівську консерваторію (клас проф. С. Кребса - скрипка). В цьому ж році приступає до керівництва хором польського “Товариства людового" в містечку Городенці на Станіславщині. Одночасно керує міським хором “Боян” та організовує хорові колективи в навколишніх селах - Стрільче і Ясенів-Пільний. А згодом - в Чернелиці i Копичинцях. “Чернелицький хор, - згадує Р. Мулярчук, - хор під його (Я. Смеречанського - П.Г.) керівництвом був удостоєний у 1938 році виступуна львівському радіо. На той час це була незвична подія" [4, 7].

Одночасно 3 диригентською діяльністю Я. Смеречанський не покидає спроб і на композиторській ниві. В 30-х роках у “Каталозі пісень галицьких композиторів” зафіксовано його шість пісень на вірші Т. Шевченка і І. Франка. Я. Смеречанський написав музику на багато віршів М. Шашкевича, М. Рильського, О. Маковея, А. Малишка та інших поетів.

3 початком війни в 1941 році композитор переїжджає до Заліщик. Організований ним тут хор брав участь у Першому Краєвому конкурсі хорів Галичини, присвяченому 100-річчю від дня народження М. Лисенка, який проходив у Львові в 1942 році. Як згадує учасниця хору Ольга Плеш: “До Львова ми їхали підводами, під керівництвом Я.В. Смеречанського співали пісень, жартували. На цьому конкурсі зайняли провідне місце по співу, а по костюмах - перше" [4, 8] I дійсно, за результатами конкурсу Заліщицький хор був на шостому місці серед містечкових хорів, а також “...відзначений першою премією за стилеву народну ношу мішаний хор із Заліщик, зібрав оплески за пісню “Та нема гірш нікому” Лисенка" [1, 33].

Диригентська діяльність Ярослава Смеречанського тривала більше як півстоліття. За цей період ним було створено близько 40 хорів, які успішно пропагували твори українських композиторів, народні пісні, серед широкого кола слухачів. Серед найвідоміших хорових колективів, створених Маестро Смеречанським слід назвати мішаний хор с. Чернелиці (згадуваний вище); Заліщицький мішаний хор, що брав участь у Лисенківському конкурсі; Добрівлянський народний хор - учасник УІ Всесвітнього Фестивалю Молоді в Москві (нагороджений бронзовою медаллю). Двічі цей колектив знімався в кінострічках "Пісні над Дністром" та "Над Дністром"; чоловіча хорова капела м. Заліщики; хор хлопчиків при Заліщицькій середній школі; хори в селах: Торське, Колодрібка, Бедриківці, Киселів та багато інших хорових колективів.

Під його керівництвом різного типу хорові колективи займали призові місця на різноманітних конкурсах, фестивалях, демонструючи високу професійну майстерність. Так у 1946 році учнівський хор м. Заліщик здобув перше місце на огляді дитячої самодіяльності. Який проходив у м. Києві. Самодіяльний хор с. Торське, організований Я. Смеречанським у 1963 році, рішенням колегії Міністерства культури отримав почесне звання "Народний самодіяльний хор".

Серед досить об'ємної творчої спадщини композитора найбільш популярними $є$ його хорові композиції "Пасла дівка лебеді", "Бистра вода”, на шевченківську поезію - "Заповіт" - для соліста-баса і чоловічого хору (цей твір Леся Цалай-Якименко використала у своїй дисертації на тему "Заповіт" Тараса Шевченка в музиці" (1964), “Гусарка”, “Село”. Та найвідоміший на нашу думку $є$ композиція Я. Смеречанського на поезію Т. Шевченка “Тече вода в синє море”, яка стала окрасою репертуару багатьох відомих чоловічих хорових колективів. Серед них: чоловіча хорова капела “Бескид” м. Дрогобича (керівник Степан Стельмащук), український хор в Польщі 


\section{ДО ІСТОРЇ ХОРОВОГО МИСТЕЦТВА ТЕРНОПЛЫЩИНИ: ЯРОСЛАВ СМЕРЕЧАНСЬКИЙ ХОРОВИЙ ДИРИГЕНТ, КОМПОЗИТОР, ПЕДАГОГ (до 110-ї річниці від дня народження)}

“Журавлі” (керівник Ярослав Полянський), чоловічий камерний хор “Боян Дрогобицький” (керівник Петро Гушоватий) та багато інших. До речі твір “Тече вода...” увійшов до 7-ми томного видання “Пісенний Кобзар", яке укладене відомим хормейстером, Героєм України Павлом Івановичем Муравським. "Працюючи над добором нот для запису покладеної на хорову музику Шевченкової поезії, - пише Павло Іванович, - я уклав це унікальне нотне зібрання. За всю історію музичного освоєння поетичної спадщини Тараса Шевченка "Пісенний Кобзар" - перше найповніше зібрання хорових творів на слова нашого національного генія" [3, 5].

На прохання відомого культурософа, автора Всеукраїнського мистецького проекту "Україна співає "Кобзаря", редактора "Пісенного Кобзаря" Олександра Шокала твір Я.Смеречанського “Тече вода..” озвучений чоловічим хором "Боян Дрогобицький” Дрогобицького державного педагогічного університету імені Івана Франка (керівник П. Гушоватий) i внесений до фонохрестоматії, випуск якої здійснено за підтримки міністерства культури України.

Авторові цих рядків судилося бути присутнім на творчій зустрічі хорової капели “Бескид” (як їі учасник) і відомого подільського мистця Ярослава Смеречанського, яка відбулася в травні 1980 року в Заліщиках. Тоді 70-літній Маестро щиро подякував “бескидянам” за концерт, за виконаний твір “Тече вода...” і побажав хористам нових творчих успіхів.

У композиторському доробку Я. Смеречанського біля 500 опусів - камерна інструментальна музика, твори для духового оркестру, скрипки, фортепіано, а також численні оригінальні хори, вокальні ансамблі, солоспіви. Всі твори пройняті інтонаціями народного мелосу, захоплюють мелодійністю та оригінальністю гармонії.

Ярослав Смеречанський проявив себе активним громадським діячем та вмілим організатором.

В 1947 році організував у Заліщиках дитячу музичну школу, яка була відкрита у вересні 1946 року як філіал Чортківської. Завдяки зусиллям Я. Смеречанського з 1947 року вона почала діяти як самостійний музичний заклад. 3 цього часу розпочалася робота по будівництву. Про цей факт згадує колишній вчитель фізики Маркіян Лубкович: “Ярослав Васильович був скромною людиною, але дуже вимогливою до себе. Виношував думку про те, щоб в Заліщиках була своя музична школа, бо з вересня 1946 р. вона була філією Чортківської музичної школи і мала свої класи в Будинку піонерів. Я, голова батьківського комітету, разом
3 активом інших батьків та Я. Смеречанським звернулись до голови райвиконкому Я. Сороки і зуміли його переконати в потребі будівництва музичної школи. Ми, бідні “як коні на припоні”, почали будівництво двоповерхової музичної школи за кошти батьків (хоч гроші не можна було “гласно” збирати), а вже в 1964 школа була збудована" [4, 12].

Як педагог музичної школи по класу скрипки та організатор диригентських курсів виховав цілу плеяду учнів, які стали професійними музикантами-педагогами, виконавцями, що працюють у відомих колективах, різноманітних навчальних закладах не тільки в багатьох куточках нашої України, але й закордоном Польщі, Канаді, США та Англії. Так у Тернопільському музичному училищі (сьогодні музичний коледж імені С.Крушельницької) працюють Іван Романко, Надія Дорожинська; Юрій Романко скрипаль оркеструЛьвівської Національної опери; Іван Оленчик - соліст Державного симфонічного оркестру в Москві та викладач по класу кларнета у Вищому музичному інститугі імені Гнссіних (Росія); Василь Барабаш працює у Вітебському музичному училищі(Білорусія).

Випускники Я. Смеречанського успадкували від свого вчителя велику любов до музики, високий професіоналізм, працелюбність, скромність, вимогливість до себе та інші прекрасні людські якості.

З 1992 року колектив Заліщицької музичної школи очолює учень Ярослава Смеречанського Ярема Бутківський.

Хочеться зацитувати листа, якого в 1995 році Вчитель написав своєму учневі: “Директорові Заліщицької ДМШ п.Яремі Бутківському! За ініціативу, організацію і участь уздійсненні мойого авторського концерту та захоплення цією ідеєю учасників, виконавців і Відділу культури Заліщицької Державної адміністрації та їі матеріального вкладу в торжеств енне його проведення - через Вашу особу, дорогий Яремо Івановичу, Вам особисто і всім учасникам - до вщерть заповненого залу глядачів включно, цього дорогого для мене величавого свята велику, сердечну, щиру подяку і низький уклін висловлюю. Ваш Ярослав Васильович Смеречанський” [4, 23].

Ярослав Васильович був професійним знавцем музики. Грав на багатьох інструментах: скрипці, фортепіано, гітарі, мандоліні, цитрі, фісгармонії, на деяких духових інструментах, самостійно освоїв гру на бандурі. Коли Тернопільській області передали тірольський оркестр, його віддали Я. Смеречанському, бо лише він міг з ним працювати. 


\section{ДО ІСТОРІЇХОРОВОГО МИСТЕЦТВА ТЕРНОПЛЬЩИНИ: ЯРОСЛАВ СМЕРЕЧАНСЬКИЙ ХОРОВИЙ ДИРИГЕНТ, КОМПОЗИТОР, ПЕДАГОГ (до 110-ї річниці від дня народження)}

Музичний талант не єдиний дар, яким був наділений маестро Смеречанський. Із слів його старшої дочки Лесі довідуємося, що батько мав неабиякий малярський хист. Малював портрети T. Шевченка I. Богуна, сцени з життя українського села. Добре знав математику, фізику. "З легкістю користувався законами електрики, - згадує п. Леся. - А найбільше батько любив відпочивати, працюючи 3 деревом. Майстрував різні речі: дерев'яні ложки, малі і маленькі скрипочки (8-4), використовуючи дерево грушки. Вишивав “хрестиком” під час воєнних бомбардувань, щоб заспокоюватись у паніці...” $[4,35]$.

Ярослав Смеречанський був глибоко освіченою людиною. В нього була велика бібліотека - багато видань польською, німецькою, російською мовами, якими митець володів.

Композитор спілкувався з багатьма відомими людьми, які часто відвідували родину Смеречанських в Заліщиках. Серед них: Вадим Стеценко, Рада Лисенко (відома піаністка, внучка М. Лисенка), професор Стефанія Павлишин, відомий музикознавець Марія Білинська, композитори - Анатолій Кос-Анатольський, Г.Верьовка; виконавці - бандурист Михайло Баран, піаніст Роман Криштальський; диригенти Богдан і Михайло Антківи, Степан Стельмащук та багато інших діячів культури не тільки Тернопільщини, Львівщини, але й Польщі, Канади, США.

Позитивну оцінку творчості Ярослава Смеречанського дав народний артист України, лауреат Державної премії ім. Т. Шевченка, професор, академік Микола Колесса.

Висновок. Велика безкорислива працездатність, патріотизм, високий професіоналізм, щирість і людяність у стосунках з товаришами - ось основні риси характеру відомого диригента, талановитого педагога, композитора, суспільно-громадського діяча Ярослава Васильовича Смеречанського, який своєю працею зробив великий внесок у розвиток української музичної культури.

\section{ЛІТЕРАТУРА}

1. Альманах Першого краєвого конкурсу хорів у Галичині. [Заг. ред. Є. Цегельського]. - Львів, 1943. - C.29.

2. Бурбан М. Хорове виконавство Львівщини. Хори. Диригенти. Довідник. / М.Бурбан. Дрогобич-Львів, 1999. - С.527

3. Муравський П. (укладач). Пісенний Кобзар. Хорова Шевченкіана. / П. Муравський /. - К., "Просвіта", 2014. - Т.1. - С.5; Т.2. - С. 65.

4. Тракало О. [Заг.ред.] Маестро Наддністрянського краю / О.Тракало /. - Чернівці “Місто”, 2009. - С.6$8 ; 23-35$.

\section{REFERENCES}

1. Almanakh Pershoho kraievoho konkursu khoriv u Halychyni (1943). [Almanac of the First Regional Contest of Choirs in Galicia]. (Ed.).Ye.Tsehelskyi. Lviv, p.29.[in Ukrainian].

2. Burban, M. (1999). Khorove vykonavstvo Lvivshchyny. Khory. Dyryhenty. Dovidnyk [Choral performance of Lviv region. Choirs. Conductors. Directory]. Drohobych-Lviv, p.527.[in Ukrainian].

3. Muravskyi, P. (Ed.). (2014). Pisennyi Kobzar. Khorova Shevchenkiana [Song Kobzar. Choral Shevchenkiada]. Kyiv, "Prosvita", Vol.1. p.5; vol.2. p. 65. [in Ukrainian].

4. Trakalo, O.(Ed.). (2009). Maestro Naddnistrianskoho kraiu [Maestro of Naddnistryanskiy region]. Chernivtsi "Misto", pp.6-8; 23-35.[in Ukrainian].

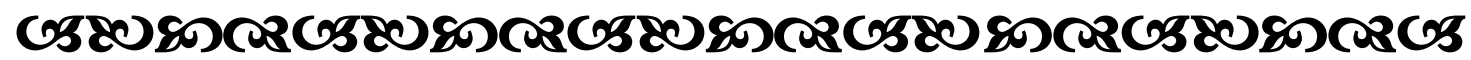

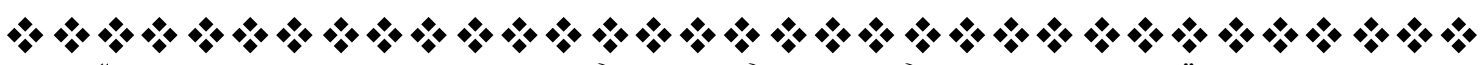 "Світ має смисл, і смисл ией відчутний для нас у дзерқалі музики".}

Терман Тессе німещький письменник, білософб

“Фосконала музика призводить серие в тақий же Ж стан, яқий відиуваєш, насолоджуючись присутністю улюбленої істоти, тобто музиқа дає, безсумнівно, найясқравіше щастя, яқе тільки можливе на землі".

Стендаль (Анрі-Марі Бейль) франиузький письменник

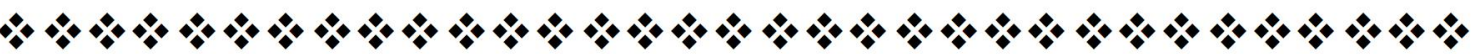

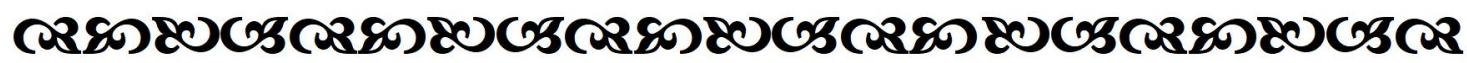

